\title{
Financial Reporting Quality, audit Quality, and Investment Efficiency: Evidence from Indonesia
}

\author{
Sylvia Veronica Siregar ${ }^{1}$, Siti Nuryanah ${ }^{2}$ \\ \{sylvia.veronica@ui.ac.id ${ }^{1}$, snuryanah@ui.ac.id $\left.{ }^{2}\right\}$ \\ Universitas Indonesia, Indonesia ${ }^{1,2}$
}

\begin{abstract}
The aim of our study is to examine the effect of financial reporting quality and audit quality on investment efficiency. We also examine whether auditor quality moderates the association between financial reporting quality and investment efficiency. The external auditor is one of the corporate governance mechanisms, especially vital related to disclosure principle. Our observations consist of listed firms in Indonesia stock exchange with total observations are firm-years. The results of our study show that financial reporting quality has a significant and positive association with investment efficiency. We also find similar findings in our subsamples of over-investment. We expect that audit quality has a positive direct effect and moderating effect. However, we do not find supporting evidence for this.
\end{abstract}

Keywords: audit quality, financial reporting quality, investment efficiency

\section{Introduction}

There are many extant studies examining investment efficiency and financial reporting quality/FRQ [1]. According to Biddle et al. [1] the argument underlying the association between FRQ and investment efficiency is due to to higher FRQ leads to a decline in information asymmetry between firms and outsiders' capital holders, by making firms' profitable projects more evident to those capital providers. In addition, higher FRQ also mitigates adverse selection issue. Higher FRQ amso limit managerial incentives to invest in non-value added or value is decreasing investments (such as, engage in investment with the purpose of empire building due to excess cash flows). Higher FRQ aids in creating effective contracts to avoid less efficient investment and also to increase external providers of capital' ability to oversee the firm's investment decisions.

FRQ is also had an association with audit quality. [2] argue that when users are unsure about the reliability of financial statements, they will look at to the auditor's report. External auditors play a significant role in ensuring that financial statements are free from material misstatements. DeAngelo [3] argues that larger audit firms supply a higher level of audit quality. Larger auditors have less incentive to behave opportunistically because they have 'more to lose' from supplying lower audit quality. These auditors have a reputation (or brand name collateral), which cause them to suffer if they give lower audit quality. There is evidence showing that firms audited by larger audit firms are less likely to engage in earnings management [4]. The external auditor is a gatekeeper of FRQ and has an important role in corporate governance as financial reporting is one of the important source of information for outsiders, hence it is very important to increase firm's transparency.

In this study, we also examine how audit quality affects investment efficiency and also how audit quality moderates the FRQ effect on investment efficiency. The argument underlying this is higher FRQ decreases information asymmetry and increase the reliability of accounting numbers, which due to effective monitoring 
by high quality auditors, the impact of FRQ on investment efficiency will be stronger for firms audited by high quality auditors [5].

The contribution of this study is adding to the literature of investment efficiency by providing empirical evidence in the context of one of emerging markets, Indonesia. Extant studies usually suggest that FRQ of listed firms in emerging markets is significantly lower than that of listed firms in developed countries, thus this study can provide "lower boundary conditions" of the importance of financial reporting. Furthermore, this study also provides a contribution, especially to literature in the emerging country, on FRQ and audit quality role in mitigating investment efficiency, as well the moderating effect of audit quality to improve the association between FRQ and investment efficiency.

\section{Literature Review And Hypotheses Development}

Financial reporting has a crucial role in improving firms' investment decisions by facilitating better capital allocation [6]. Biddle et al. [7] define a firm as investing efficiently "if it undertakes projects with a positive net present value (NPV) under the scenario of no market frictions such as adverse selection or agency costs". Hence, under-investment means giving up positive NPV projects assuming no adverse selection and overinvestment means making an investment in projects with negative NPV.

Higher FRQ increase management accountability by allowing better monitoring by investors, and thus reducing adverse selection and moral hazard, which means decreasing information asymmetries. Higher FRQ also provide managers with high quality information to help them in making more informed investment decisions as managers have a higher ability to identify profitable projects [5]. Based on this argument, high FRQ will mitigate overinvestment and underinvestment, or in other words has a positive association with investment efficiency.

H1: FRQ has a positive association with investment efficiency.

DeAngelo[3] argues that large auditors can provide high quality audit due to they have more to loose if they provide lower than expected audit quality. They also have more resources for providing training to their auditors and they will experience greater losses (example: in the form of reputation damage) if they provide poor audit quality. Becker et al. [4] find the support of this argument by showing that firms audited by large audit firms are less susceptible to earnings management activities.

Literature also suggests that companies having ample investment opportunities demand high quality audits due to the limited ability of their internal control to keep up with the growth speed, which means an increase in control and audit risk [8]. Engaging large auditors (such as Big 4) is expected to be beneficial for firms with ample investment opportunities, as those firms have higher tendency to engage in earnings management (i.e. by increasing abnormal accruals) to maintain its growth, thus high quality audit will mitigate earnings management (abnormal accruals) for such firms [5]. Lower abnormal accruals reduce information asymmetry, which in turn lower investment inefficiency.

$\mathrm{H} 2$ : Audit quality has a positive association with investment efficiency. In addition, we also examine the moderating role of audit quality on the association of FRQ and investment efficiency. We conjecture that positive association of FRQ and investment efficiency is much stronger for firms audited by the high quality auditor (Big 4) than firms audited by the low quality auditor (Non Big 4). High quality auditor able has a larger effect in reducing information asymmetry and reducing discretionary accruals (earnings management). Hence, we expect audit quality to strengthen the positive association between FRQ and investment efficiency.

H3: Positive association between FRQ and investment efficiency is stronger in firms audited by Big 4 than that audited by Non Big 4

\section{Research Method}

Following is our research model to test the hypotheses:

InvEffi,t $=\beta 0+\beta 1$ FRQi,t $+\beta 2$ AudQi,t $+\beta 3$ FRQi,t*AudQi,t $+\beta 4$ Tangi, $t+\beta 5$ TobinsQi,t $+\beta 6$ CFOi,t + $\beta 7$ Levi, $t+\beta 8$ Sizei, $t+\beta$ A Agei, $t+\beta 10$ Lossi, $t+$ ei,t (1)

To measure investment efficiency, we follow [6] and Gomariz and Ballesta [9]. We define investment inefficiency as differences between the actual level of investment and normal level of investment. The normal level of investment is determined using a regression model that predicts the investment level is determined by the level of growth opportunities). Negative differences from normal investment (underinvestment) and positive differences from normal investment (overinvestment) are deemed as investment inefficiency. Following Chen 
et al., (2011), we add indicator variable to account the differential effect for revenue increases and revenue decreases: Investi,t $=\beta 0+\beta 1$ NEGi,t-1+ $\beta 2 \%$ RevGrowthi,t-1+ $\beta 3 N E G * \%$ RevGrowthi,t-1+ei,t (2).

The invest represents the total investment which is the total capital expenditure in property, plant, and equipment/PPE, research and development minus sales of PPE. This variable is scaled by lagged total assets. \% RevGrowth is the change in revenue. The NEG is an indicator variable of 1 if negative revenue growth and 0 if otherwise. We estimate this model cross-sectionally for each industry. We multiply the absolute value of the residuals from this model by negative 1 , so that the higher amount indicates higher investment efficiency.

In our study, we use the aggregate measure of FRQ based on three proxies that have been widely used in extant studies. We do this because we believe that one proxy cannot cover all aspects of financial reporting quality and also by using multiple proxies we expect to increase the generalizability of our results [8]. By using these proxies we expect that (if any) the bias in one proxy will be offset by other proxies.

Following Gomariz and Ballesta [9], we measure the FRQ based on three different proxies. The first proxy is developed by [10]. The second proxy is based on Kasznik [10]: We use Dechow and Dichev [11] model as the third proxy: We use the residuals from all these models and multiply by negative 1 , so that higher value represents greater FRQ. Our audit quality variable is measured based on audit company size, where 1 if firm audited by Big 4 and 0 if otherwise. DeAngelo [3] argues that larger audit company is associated with higher audit quality. Following Biddle et al. [7], Chen et al. [6], Gomariz and Ballesta [9], we include several control variables in our research model, which are Tangible Assets (TangAsset) that is the ratio of tangible asset to total asset, Tobin's Q (TQ) to measure growth opportunities, Cash Flow from Operations (CFO), Leverage (Lev), Size represents firm size, firm age (FirmAge), and Loss (indicator variable where 1 if negative earnings and 0 if otherwise).

We collect financial reporting and auditor data from Datastream as well as firms' financial reports. Consistent with previous studies [1], we excluded financial firms because these firms have a different nature of investment and also they are highly regulated firms. Our study covers the period of 2012-2015. Based on these criteria and availability of data, our observations consist of 668 firm-years.

\section{Results and Discussion}

In average, the descriptive statistics show that investment inefficiency is quite high (which is about $4 \%$ of total assets). Mean value of FRQ is $-11,83 \%$ which also indicates that our samples company engage in earnings management quite high (almost 12\% of total assets). Most of our samples are audited by Non Big 4 (61.68\%). Correlation matrix of all variables can be seen in Table 2. FRQ and investment efficiency has positive association. The same applies for association between audit quality and investment efficiency.

Based on regression results in Table 3, we find that FRQ has positive and significant association with investment efficiency. This result lends support to our H1. This finding is consistent with that of previous research [7]; [6]; [9]). Higher FRQ can mitigate investment efficiency because it decreases information asymmetry by making company's financial statements more transparent which enable external capital suppliers to easily monitor management. This will reduce moral hazard. FRQ also means capital suppliers able to identify company's prospective projects, and thus reduce adverse selection problem. This finding shows that even though firms in less developed countries considered to have lower quality financial reporting than those in developed countries, FRQ still plays key role in improving investment efficiency. 
Table 1. Descriptive Statistics

\begin{tabular}{|c|c|c|c|c|}
\hline Variable & Mean & Std Dev & Minimum & Maximum \\
\hline InvEff & -0.0404 & 0.0332 & -1.6098 & -0.0001 \\
\hline FRQ & -0.1183 & 0.1177 & -0.6406 & -0.0002 \\
\hline TangAsset & 0.4813 & 0.2081 & 0.0269 & 0.9803 \\
\hline$T Q$ & 1.7118 & 1.6480 & 0.3002 & 8.1383 \\
\hline CFO & 0.0715 & 0.1129 & -0.3307 & 0.6627 \\
\hline Lev & 0.5421 & 0.2650 & 0.0113 & 1.6649 \\
\hline Size & 28.2439 & 1.8172 & 23.3569 & 32.9378 \\
\hline $\begin{array}{c}\text { FirmAg } \\
e\end{array}$ & 3.5490 & 0.3940 & 2.3026 & 4.6444 \\
\hline & Big 4 & Non Big 4 & & \\
\hline AudQ & $38.32 \%$ & $61.68 \%$ & & \\
\hline & Negative Earnings & Positive Earnings & & \\
\hline Loss & $22.16 \%$ & $77.84 \%$ & & \\
\hline
\end{tabular}

Table 2: Correlation Matrix

\begin{tabular}{|c|c|c|c|c|c|c|c|c|c|c|}
\hline & InvEff & FRQ & AudQ & $\begin{array}{c}\text { TangAss } \\
\text { et }\end{array}$ & TQ & $\mathrm{CFO}$ & Lev & Size & $\begin{array}{c}\text { FirmA } \\
\text { ge }\end{array}$ & $\begin{array}{c}\text { Los } \\
\mathrm{s} \\
\end{array}$ \\
\hline InvEff & $\begin{array}{r}1 \\
0.087\end{array}$ & & & & & & & & & \\
\hline FRQ & $\begin{array}{r}1 \\
0.054\end{array}$ & $\begin{array}{l}1 \\
-\end{array}$ & & & & & & & & \\
\hline AudQ & $\begin{array}{l}8 \\
-\end{array}$ & 0.0116 & 1 & & & & & & & \\
\hline $\begin{array}{l}\text { TangAs } \\
\text { set }\end{array}$ & $\begin{array}{r}0.195 \\
7 \\
-\end{array}$ & 0.0654 & 0.0527 & 1 & & & & & & \\
\hline TQ & $\begin{array}{r}0.013 \\
8 \\
-\end{array}$ & 0.0184 & 0.2824 & -0.054 & 1 & & & & & \\
\hline $\mathrm{CFO}$ & $\begin{array}{r}0.053 \\
3 \\
-\end{array}$ & 0.0342 & 0.2749 & -0.0625 & $\begin{array}{r}0.484 \\
-\end{array}$ & 1 & & & & \\
\hline & 0.073 & - & - & & 0.063 & - & & & & \\
\hline Lev & $\begin{array}{r}2 \\
0.096\end{array}$ & 0.1122 & 0.0911 & 0.1286 & $\begin{array}{r}3 \\
0.136\end{array}$ & 0.1614 & $\begin{array}{r}1 \\
0.072\end{array}$ & & & \\
\hline Size & 4 & 0.0384 & 0.4014 & -0.0408 & 8 & 0.2419 & $\begin{array}{l}9 \\
-\end{array}$ & 1 & & \\
\hline $\begin{array}{l}\text { FirmAg } \\
\text { e }\end{array}$ & $\begin{array}{r}0.064 \\
5\end{array}$ & -0.015 & 0.2039 & -0.053 & $\begin{array}{r}0.146 \\
2 \\
-\end{array}$ & 0.164 & $\begin{array}{r}0.058 \\
5\end{array}$ & 0.2703 & 1 & \\
\hline Loss & -0.087 & 0.0351 & 0.1091 & 0.2939 & $\begin{array}{r}0.090 \\
8\end{array}$ & $0.2068^{-}$ & $\begin{array}{r}0.343 \\
7\end{array}$ & $0.1727^{-}$ & $0.1118^{-}$ & 1 \\
\hline
\end{tabular}


Table 3: Regression Result

\begin{tabular}{|l|l|l|l|l|}
\hline Variables & Coeff. & t stat & \multicolumn{2}{|c|}{ Sign. } \\
\hline Cons. & -0.0151 & -2.5000 & 0.0120 & $* *$ \\
\hline$F R Q$ & 0.0170 & 1.3200 & 0.0930 & $*$ \\
\hline AudQ & 0.0029 & 0.6200 & 0.2690 & \\
\hline$F R Q * A u d Q$ & 0.0132 & 0.6400 & 0.2605 & \\
\hline Tang & -0.0357 & -4.3600 & 0.0000 & $* * *$ \\
\hline TobinsQ & 0.0002 & 0.1400 & 0.4440 & \\
\hline CFO & -0.0349 & -2.5500 & 0.0055 & $* * *$ \\
\hline Lev & -0.0087 & -1.3400 & 0.0905 & $*$ \\
\hline Size & 0.0019 & 1.8100 & 0.0350 & $* *$ \\
\hline Age & 0.0035 & 0.7800 & 0.2170 & \\
\hline Loss & 0.0016 & 0.4600 & 0.3245 & \\
\hline R2 & 0.0691 & & & \\
\hline F stat & 0.0000 & $* * *$ & $*$ & \\
\hline$* * *$ significance level of $1 \%, * *$ significant level of $5 \%$, & significant level of $10 \%$ \\
\hline
\end{tabular}

We also separate our samples into over-investment subsamples and under-investment subsamples (untabulated) The result for overinvestment subsamples is quite consistent with the result of all samples. FRQ has a positive association with investment efficiency in the over-investment setting. This finding is also consistent with findings from previous studies, such as Biddle et al. [7] and Chen et al. [6]. Elaoud \& Jarboui [5] also find a similar result for subsamples overinvestment. However, under-investment sub samples show contrary results. We do not find a positive association of FRQ between investment efficiency. The result even shows a negative association of FRQ and investment efficiency.

We initially predicted that FRQ has a positive association with investment efficiency because it can reduce information asymmetry between management and external parties. In the case of a company has a lack of funds (which usually resulted in under-investment), external suppliers may have scepticism in the quality of financial reporting. Hence, even though the company's financial reporting is of high quality, external users do not consider their reports of high quality, and hence resulted in a negative association between FRQ and investment efficiency. There may be another explanation related to the amount of investment efficiency. From statistics descriptive (untabulated), the level of inefficiency in under-investment is about 5,3\% of total assets, while overinvestment has a lower level of investment inefficiency of 3,4\%. Under-investment firms exhibit a higher (lower) level of investment efficiency (inefficiency). This condition may cause even high FRQ is not sufficient to reduce the level of investment inefficiency.

Initially we expect that higher audit quality also has a positive association with investment efficiency. However, contrary to initial expectation, our study finds an insignificant association between audit quality and investment efficiency ( $\mathrm{H} 2$ is not supported). Consistent with this result, we also do not find the significant moderating effect of audit quality on the association of financial reporting quality and investment efficiency.

When the samples are divided into over-investment and under-investment firms, we also do not document any significant positive results for our over-investment subsamples. Although this result is inconsistent with our hypothesis, this result is consistent with Chen et al. [6]. This insignificant results of audit quality, may also show that audit quality provided by big and small audit firms are not necessarily different. All auditors must follow audit procedures in accordance with auditing standards. They also regularly inspected by auditors' regulator (Center for Supervision of Financial Professions under Ministry of Finance/Pusat Pembinaan Profesi Keuangan (PPPK) Kementerian Keuangan). However, in our under-investment subsamples, we document that audit quality has a negative and significant association with investment efficiency. The explanation for this result is similar to that of FRQ, which also shows a negative association.

These results are inconsistent with Elaoud \& Jarboui [5], who find that high quality auditor mitigates investment inefficiency. However, they use a different measure of audit quality. They use auditor specialization, instead of auditor size. It is possible that our audit quality measure is not the best measure of 
audit quality [12]. We do not use auditor specialization because to measure this variable we need information about audit firms' clients in terms of numbers and total assets and/or total revenue. We only have the data of only listed clients, which is not suitable as a basis to measure auditor specialization as most of the audit firms have a larger client base from private companies. Based on data from descriptive statistics, most of our samples are audited by small audit firms (Non Big 4). It is possible that Big 4 provide higher audit quality but due to only small proportions of our samples employed Big 4 audit firms, then in average there is no significant effect of audit firm size on investment efficiency.

\section{Conclusion}

Our results show that FRQ has a positive association with investment efficiency (for all samples and especially over-investment condition). However, we do not find supporting evidence for our audit quality variable. The findings of our study show that audit quality does not have positive direct and moderating effect on investment efficiency. These findings do not necessarily suggest that audit quality is not a significant factor in this relationship, because there are a lot of audit quality measures and in our study we only use one measure, which is audit firm size. There are several limitations to our study. We employ a parsimonious model to measure investment efficiency. We leave this to future research to formulate a better model to measure investment efficiency. We only include 3 measures of FRQ to compute our FRQ variable. There are other alternative models to measure FRQ, such as [13]. Our audit quality measure is only based on auditor size. Future studies may use another measure, such as industry specialization [14]. Other governance mechanisms, other than audit quality, may also affect investment efficiency. For example, Biddle et al. [7] for example included institutional ownership and analyst following as corporate governance mechanisms.

\section{Acknowledgements}

We would like to acknowledge research funding from DIKTI research grant.

\section{References}

[1] Biddle, G. C., \& Hilary, G. Accounting quality and firm-level capital investment. The Accounting Review, 81(5), 963-982 (2006).

[2] Tsipouridou, M., \& Spathis, C. Earnings management and the role of auditors in an unusual IFRS context: The case of Greece. Journal of International Accounting, Auditing and Taxation, 21(1), 62-78 (2012).

[3] DeAngelo, L. E. Auditor size and audit quality. Journal of Accounting and Economics, 3(3), $183-199$ (1981).

[4] Becker, C. L., DeFond, M. L., Jiambalvo, J., \& Subramanyam, K. R. The effect of audit quality on earnings management. Contemporary Accounting Research, 15(1), 1-24 (1998).

[5] Elaoud, A., \& Jarboui, A. Auditor specialization, accounting information quality and investment efficiency. Research in International Business and Finance (2017).

[6] Chen, F., Hope, O. K., Li, Q., \& Wang, X. Financial reporting quality and investment efficiency of private firms in emerging markets. The Accounting Review, 86(4), 1255-1288 (2011).

[7] Biddle, G. C., Hilary, G., \& Verdi, R. S. How does financial reporting quality relate to investment efficiency? Journal of Accounting and Economics, 48(2), 112-131 (2009).

[8] Cahan, S. F., Godfrey, J. M., Hamilton, J., \& Jeter, D. C. Auditor Specialization: The Influence of Investment Opportunities. Available at https://papers.ssrn.com/sol3/papers.cfm?abstract_id=920490 (2006).

[9] Gomariz, M. F. C., \& Ballesta, J. P. S. Financial reporting quality, debt maturity and investment efficiency. Journal of Banking \& Finance, 40, 494-506 (2014).

[10] Kasznik, R. On the association between voluntary disclosure and earnings management. Journal of Accounting Research, 37(1), 57-81 (1999).

[11] Dechow, P. M., \& Dichev, I. D. The quality of accruals and earnings: The role of accrual estimation errors. The Accounting Review, 77(s-1), 35-59 (2002).

[12] Siregar, S. V., \& Utama, S. Type of earnings management and the effect of ownership structure, firm size, and corporate-governance practices: Evidence from Indonesia. The International Journal of Accounting, 43(1), 1-27 (2008).

[13] Stubben, S. R. Discretionary revenues as a measure of earnings management. The Accounting Review, 85(2), 695717 (2010).

[14] Balsam, S., Krishnan, J., \& Yang, J. S. Auditor industry specialization and earnings quality. Auditing: A Journal of Practice \& Theory, 22(2), 71-97 (2003). 